\title{
Exposure of Baixadeiro horses to Rickettsia spp. and to ticks infected by Rickettsia amblyommatis in the Baixada Maranhense micro-region, Maranhão, Brazil
}

\section{Edvaldo Franco Amorim Filho ${ }^{1}$ Francisco Borges Costa ${ }^{1} \odot$ Jonas Moraes-Filho $^{2}$ Ana Clara Gomes dos Santos ${ }^{1}$ Tássia Lopes do Vale ${ }^{1}$ Andréa Pereira da Costa ${ }^{1}$ Arannadia Barbosa Silva $^{3}$ Marcelo Bahia Labruna ${ }^{2}$ Rita de Maria Seabra Nogueira ${ }^{*}$ (?)}

${ }^{1}$ Departamento de Patologia, Ciência Animal, Universidade Estadual do Maranhão (UEMA), Cidade Universitária Paulo VI, Avenida Lourenço Vieira da Silva, 65055-310, São Luís, MA, Brasil. E-mail: grita62@hotmail.com. *Corresponding author.

${ }^{2}$ Departamento de Medicina Veterinária Preventiva e Saúde Animal, Faculdade de Medicina Veterinária e Zootecnia (FMVZ), Universidade de São Paulo (USP), São Paulo, SP, Brasil.

${ }^{3}$ Faculdade Vale do Aço (FAVALE), Açailândia, MA, Brasil.

ABSTRACT: The aim of this study was to investigate exposure of Baixadeiro horses to Rickettsia spp. and to ticks infected by Rickettsia in the Baixada Maranhense (lowlands) micro-region, state of Maranhão. A total of 258 horses were tested for Rickettsia rickettsii, Rickettsia amblyommatis and Rickettsia bellii using the immunofluorescence assay (IFA). Overall, 58.91\% (152/258) of the horses were seroreactive for at least one Rickettsia species, and $85.27 \%$ of the horses were infested with one or more species of tick, which were identified as Dermacentor nitens (93.63\%), Amblyomma cajennense sensu stricto (4.55\%) and Rhipicephalus (Boophilus) microplus (1.82\%). These ticks were subjected to DNA extraction and were tested using the polymerase chain reaction (PCR), targeting two rickettsia genes: citrate synthase gene (gltA) and $190 \mathrm{kDa}$ outer membrane protein gene (ompA). Three specimens of A. cajennense s.s. were positive. BLAST analyses on the nucleotide sequences obtained from the PCR products showed that these were 99-100\% identical to the corresponding sequences of R. amblyommatis. Thus, results indicate that $R$. amblyommatis and/or a strain very close to this is circulating in ticks in this micro-region.

Key words: Baixadeiro horse, ticks, Rickettsia spp., Maranhão.

Exposição dos cavalos Baixadeiro a Rickettsia spp. e carrapatos infectados pela Rickettsia amblyommatis na Baixada Maranhense, microrregião do Estado do Maranhão, Brasil

RESUMO: $O$ objetivo deste estudo foi verificar a exposição e a infecção de cavalos baixadeiro e carrapatos por Rickettsia spp. na microregião da Baixada Maranhense do Estado Maranhão. Um total de 258 cavalos foi testado pelo ensaio de Imunofluorescência Indireta (IFI) para Rickettsia rickettsii, Rickettsia amblyommatis e Rickettsia bellii. Deste total, 58,91\% (152/258) foram sororreativos para pelo menos uma espécie de Rickettsia sp., e 85,27\% cavalos estavam infestados por uma ou mais espécies de carrapatos identificados como Dermacentor nitens (93,63\%), Amblyomma cajennense sensu stricto (4,55\%) e Rhipicephalus (Boophilus) microplus (1,82\%). Estes carrapatos foram submetidos à extração de DNA e testados pela reação em cadeia pela polimerase (PCR) alvejando os genes citrato sintase (gltA) e o de proteina de membrana externa de $190 \mathrm{kDa}$ (ompA). Três espécimes de A. cajennense s.s. foram positivos para Rickettsia amblyommatis. As sequências dos nucleotideos obtidas a partir dos produtos de PCR mostraram 99-100\% de identidade com as sequências correspondentes de R. amblyommatis quando analisadas pelo BLAST. Desta forma, os resultados indicam a circulação de R. amblyommatis nos carrapatos e/ou uma cepa muito próxima circulando na microrregião.

Palavras-chave: cavalo Baixadeiro, carrapatos, Rickettsia spp., Maranhão.

\section{INTRODUCTION}

Rickettsia diseases are caused by small intracellular Gram-negative rod-shaped bacteria that are members of the order Rickettsiales and family Rickettsiaceae in the Proteobacteria $\alpha$-subdivision (RAOULT \& ROUX, 1997; DUMLER et al., 2001). Some species of Rickettsia that belong to the spotted fever group are known to be zoonotic etiological agents, and currently more than 11 species of Rickettsia that are pathogenic to humans are recognized around the world (PAROLA et al., 2005; SPOLIDORIO et al., 2010; MARTINS \& MARTINS, 2014). Rickettsia rickettsii is the most pathogenic and lethal of these species. Rickettsia species are usually transmitted by ticks of the genera Amblyomma, Dermacentor and Rhipicephalus in the Americas. These ticks remain infected throughout their lives through transovarial 
and/or transstadial transmission. Wild hosts play an important role in maintaining the agent, functioning as amplifiers in the environment. Typically, these hosts are opossums (Didelphis aurita) or capybaras (Hydrochoerus hydrochaeris). They make it possible for arthropods to become infected through taking blood meals, which leads to onward transmission to humans and domestic animals (HORTA et al., 2009; LABRUNA, 2009; SOUZA et al., 2009).

The Amblyomma cajennense complex was recently assessed in the state of Maranhão, Brazil, by MARTINS et al. (2016). Their analysis showed that there were only two species (i.e. Amblyomma cajennense sensu stricto (s.s) and Amblyomma sculptum), and these were strictly related to the Amazon and savanna (Cerrado) biomes. It was noteworthy that, in some transition areas, the distribution of these two tick species overlapped. The current distribution of $A$. cajennense sensu lato (s.l.) is of great medical importance in Brazil, since Rickettsia amblyommatis presents an association with $A$. cajennense s.s and $R$. rickettsii presents an association with $A$. sculptum. $R$. rickettsii is the most important etiological agent for spotted fever in the Americas (MARTINS et al., 2016; LABRUNA, 2009; MONTENEGRO et al., 2017). There have been a few reports of $A$. sculptum infected with $R$. amblyommatis in the Atlantic rainforest, Cerrado and Pantanal biomes (ALVES et al., 2014; NUNES et al., 2015; RAMOS et al., 2015; WITTER et al., 2016).

Horses are commonly considered to be the primary host of these two tick species. In Brazil, they have an important sentinel role for Brazilian spotted fever (BSF) (SANGIONI et al., 2005; UENO et al., 2016; MONTENEGRO et al., 2017).

The horse herd of the state of Maranhão is the second biggest in northeastern Brazil and is surpassed only by the state of Bahia (IBGE, 2011). In the micro-region of Baixada Maranhense (lowlands of Maranhão), which belongs to the Amazon biome, a genetic group known as the Baixadeiro horse is prominent. These horses are essential working animals that are used in extensive management of cattle because of their particular characteristic resistance and adaptability to flooding of grassland. Therefore, they have taken on great local socioeconomic importance. Furthermore, it should be emphasized that there is a need for conservation of this breed-group in northeastern Brazil (SILVA et al., 2012).

In the extensive farming system in which Baixadeiro horses are raised, there is lack of health management and medical-veterinary care. This favors tick infestations and; consequently, maintenance of the etiological agents that they transmit.

Studies on dogs in the state of Maranhão reported occurrences of bacteria of the spotted fever group (COSTA et al., 2015; SILVA et al., 2017). However, until now, except in relation to dogs, no studies have been performed on other animal species. Thus, the aim of the present research was to investigate exposure of Baixadeiro horses to Rickettsia spp. and its arthropod ectoparasites.

\section{MATERIALS AND METHODS}

\section{Study area}

This research was carried out in the municipalities of Santa Helena $\left(02^{\circ} 13^{\prime} \mathrm{S} ; 45^{\circ} 18^{\prime} \mathrm{W}\right)$, Pinheiro (02 $\left.31^{\prime} \mathrm{S} ; 45^{\circ} 04^{\prime} 58^{\prime \prime} \mathrm{W}\right)$ and Viana (03 13 ' S; $\left.45^{\circ} 00^{\prime} \mathrm{W}\right)$, in the Baixada Maranhense region, state of Maranhão, northeastern region of Brazil. The area consisted of flat lowlands and floodplains characterized by fields, gallery forest, mangrove swamps and lake basins with herbaceous graminoid vegetation in the wetlands (ALMEIDA, 2013).

\section{Sample collection}

Blood samples were aseptically collected from the jugular vein of 258 horses (37, 60 and 161 in the municipalities of Santa Helena, Viana and Pinheiro, respectively) between May 2012 and May 2013. Serum samples were separated, identified and kept frozen at $-20^{\circ} \mathrm{C}$ until the time of performing the serological assays.

Adult crossbred horses (female and male) of different ages, and with no external signs of clinical diseases, were sampled according to convenience, based on the accessibility of the places where the horses were kept. Additionally, a standardized questionnaire survey was applied to the owners, relating to sanitary and nutritional management of the horses.

Ticks collected from horses were individually taxonomically identified as described by BARROS-BATESTI et al. (2006) and were kept in $70 \%$ ethanol until the procedure for DNA extraction.

\section{Serological analyses}

Serum samples were tested by means of the indirect immunofluorescence assay (IFA) in order to detect IgG antibodies using crude antigens derived from three rickettsia isolates from Brazil: Rickettsia bellii strain Mogi (PINTER \& LABRUNA, 2006); R. amblyommatis strain Ac37, formerly named Candidatus Rickettsia amblyommii (LABRUNA et al., 2004a; KARPATHY et al., 2016); and Rickettsia 
rickettsii strain Taiaçu (PINTER \& LABRUNA, 2006), as previously described by LABRUNA et al. (2007).

Briefly, each serum was diluted starting at a dilution of 1:64, with phosphate-buffered saline (PBS), $\mathrm{pH}$ 7.2. Ten microliters of diluted serum was added to each well of the antigen slides. The slides were incubated at $37^{\circ} \mathrm{C}$ for 30 minutes in a humid chamber. They were then washed twice for $10 \mathrm{~min}$ per washing buffer and rinsed. After this procedure, the slides were incubated with a secondary antibody (commercial anti-horse IgG; Sigma-Aldrich, St. Louis, MO, USA), diluted with PBS, incubated at $37^{\circ} \mathrm{C}$ for $30 \mathrm{~min}$ in a humid chamber and washed twice (10min each time). After drying, each slide was examined under a fluorescence microscope (Olympus $^{\circledR}$, Tokyo, Japan). For each sample, the endpoint IgG titer that reacted with each of the three rickettsial antigens was determined. An endpoint titer that was at least fourfold higher for one Rickettsia species than what was observed for any other two Rickettsia species was considered probably to be homologous to the first Rickettsia species or to a very closely related species (LABRUNA et al., 2007). On each slide, negative and positive controls were tested at the dilution of 1:64. On each slide, serum samples that had previously been determined to be either unreactive or reactive to SFG rickettsiae were used as negative and positive controls, respectively (LABRUNA et al., 2007; COELHO et al., 2016).

\section{Molecular assays}

Each adult tick was subjected individually to DNA extraction using the guanidine isothiocyanate-phenol solution technique, as described elsewhere (SANGIONI et al., 2005). PCR targeting a fragment of approximately $460 \mathrm{bp}$ of the tick mitochondrial 16SrRNA gene was performed as described by MANGOLD et al. (1998), as an endogenous control. Initially, all the tick samples were screened for rickettsial infection through testing them individually with a PCR protocol using the primers CS-78 (forward) and CS-323 (reverse) targeting a 401-bp fragment of the rickettsial citrate synthase gene (gltA) (LABRUNA et al., 2004b), which is relatively conserved in all Rickettsia species (RAOULT \& ROUX, 1997). Samples yielding visible PCR products through this PCR were further tested with the primers CS-239 and CS-1069, targeting a 830-bp fragment of the gltA gene (LABRUNA et al., 2004b) and with the primers Rr190.70p and Rr190.602n, targeting a 532-bp fragment of the rickettsial $190-\mathrm{kDa}$ outer membrane protein gene (ompA) (REGNERY et al., 1991). For each reaction, both a positive control
(R. parkeri DNA strain NOD) and a negative control (water) were included. The PCR cyclic conditions for each primer pair were as previously described (LABRUNA et al., 2004b). Amplified products were analyzed afterwards by means of electrophoresis on $1.5 \%$ agarose gels stained with ethidium bromide and were viewed using an ultraviolet transilluminator.

PCR products were purified using ExoSAP-IT (USB Corp., Cleveland, OH, USA) and underwent DNA sequencing in an ABI automated sequencer (model ABI Prism 3500 Genetic, Applied Biosystems/Perkin Elmer, Foster City, CA, USA), and the resultant sequences were compared with GenBank data by means of BLAST analysis <http:// blast.ncbi.nlm.nih.gov/Blast.cgi>.

\section{Statistical analysis}

Associations between seropositivity to tick-borne pathogens and potential independent variables (age, sex, breed category and municipality) were tested using the chi-square test or Fisher's exact test. Odds ratios (OR) were calculated with $95 \%$ confidence limits. All analyses were performed using the Epi Info software, version 6.04d, CDC, Atlanta, GA, USA, 2007.

\section{RESULTS AND DISCUSSION}

A total of 258 horses in the Baixada Maranhense region, comprising 92 males (35.66\%) and 166 females (64.34\%) were sampled. All the animals had been raised in an extensive system, fed basically on Paratheria prostrata. Regarding sanitary management, 231 horses $(89.53 \%)$ had not been vaccinated against any pathogen and only $27(10.47 \%)$ had been vaccinated against Clostridium botulinum.

A total of 94 horses, comprising 36.43\% of the herds, had undergone deworming. Injectable doramectin and andiroba oil (Carapa guianensis Aubl.) had been used on $41(43.62 \%)$ and 37 $(39.36 \%)$ of the animals, respectively, and use of fenbendazole paste was also reported in relation to 16 animals (17.02\%). However, 164 horses (63.57\%) had not been dewormed. SANTOS et al. (2005) reported deworming rates of 80 and $100 \%$ for the Pantaneiro horse breed on farms in the state of Mato Grosso, Brazil, in extensive and semi-intensive management systems, respectively. These data differ from those of the present study and this suggests that the management practices used among Baixadeiro horses are poor.

Regarding the use of ectoparasiticides, 157 $(60.85 \%)$ of the animals were subjected to products 
for this purpose. Similar rates were observed by SANTOS et al. (2005), 60 and 80\% for extensive and semi-intensive management systems, respectively.

Among the 258 equine serum samples, $58.91 \%(152 / 258)$ were reactive (titer $\geq 64)$ to at least one of the Rickettsia species tested (R. rickettsii, $R$. amblyommatis and $R$. bellii) with endpoint titers ranging from 64 to 2048. Of these, 50.66\% (77/152) of the reactions were inconclusive for determining the probable antigen; $25.66 \%(39 / 152)$ of the samples showed that the antigen was $R$. amblyommatis; and $23.68 \%(36 / 152)$ of the samples showed that the presence of $R$. bellii was at least four times higher than that of any of the other antigens. Thus, these animals probably had been in contact with these two Rickettsia species or a species very closely related genotypically. A serological survey on horses performed in the state of Pará, Brazil, showed that the highest endpoint titers were around 512 and 16384 for $R$. rickettsii and $R$. amblyommatis, respectively (ANDERSSON, 2013). These high titers for $R$. amblyommatis were probably due to the presence of $A$. cajennense s.s. ticks, which present high rates of infection, as observed by SOARES et al. (2014) and COSTA et al. (2017).

Studies conducted in different places in Brazil have reported serological evidence of $R$. amblyommatis in samples from horses in the state of Mato Grosso (AMORIM et al., 2013; ALVES et al., 2014) and evidence of $R$. rickettsii in the state of Minas Gerais (GUEDES et al., 2005). In the state of São Paulo, SANGIONI et al. (2005) reported that horses were important as good sentinels. Conversely, a recent serological survey investigating Rickettsia spp. in samples from dogs in the microregion of Chapadinha, state of Maranhão, conducted by COSTA et al. (2015), reported that $18.9 \%$ (61/322) of the samples were reactive to $R$. amblyommatis or a strain very closely related to this, as the antigen possibly responsible for natural infection of the dogs. In addition, a similar study was carried out in the central-western region of Maranhão by SILVA et al. (2017), the serological results from their study suggested that dogs in the Imperatriz microregion may have been exposed to rickettsiae that were identical or closely related to $R$. amblyommatis.

Thus, it has been observed that $R$. amblyommatis is spreading across the state Maranhão, infecting ticks, dogs and horses. In the south of the state Maranhão (i.e. in the Cerrado biome), a study was conducted on 52 serum samples from horses, among which $13.46 \%$ (7/52) reacted to anti- $R$. amblyommatis antibodies (unpublished data supplied by the co-author FBC). This finding emphasizes that this bacterium is circulating throughout the state of Maranhão.

Many studies have indicated that surveys on horse and dog serum samples for anti-Rickettsia sp. antibodies are a useful method for BSF surveillance in areas where humans are exposed to $A$. aureolatum, A. ovale and A. sculptum ticks (LEMOS et al., 1996; SANGIONI et al., 2005; PINTER \& LABRUNA, 2006; VIANNA et al., 2008; OGRZEWALSKA et al., 2012; SZABO et al., 2013). COSTA et al. (2015) and COSTA et al. (2017) reported the presence of $A$. ovale and $A$. sculptum ticks on dogs in the Amazon and Cerrado biomes in Maranhão, and these are important vectors for $R$. parkeri and $R$. rickettsii, respectively (GUEDES et al., 2005; SABATINI et al., 2010). For this reason, our results emphasized the usefulness of serological surveys for monitoring changes in the epidemiology of BSF in the state of Maranhão in sentinel animals.

Between the three municipalities sampled (Santa Helena, Pinheiro and Viana), there was no statistical difference $(p \geq 0.05)$ regarding exposure of horses to Rickettsia sp. The survey showed that these areas were similar regarding exposure among horses, and that the risk that these animals might acquire rickettsial infection was uniform. This uniformity was attributed mainly to the management and the environment.

A total of 115 ticks were collected from the horses. $85.27 \%(220 / 258)$ of the animals were infested by one or more tick species. The ticks identified were: A. cajennense s.s. (18 specimens), Dermacentor nitens (92 specimens) and Rhipicephalus (Boophilus) microplus (5 specimens).

A total of 206 Baixadeiro horses (93.63\%) were parasitized only by $D$. nitens, the most abundant tick, and 11 horses had double infestations (simultaneous infestations by two tick species). Occurrences of double infestation usually consisted of $D$. nitens together with $A$. cajennense s.s or $R$. (B.) microplus as the second tick species. This had already been expected, since $D$. nitens has great specificity for this host. Among the horses infested with $A$. cajennense s.s. ticks (4.55\%), only three of the cases consisted of single infestation, while seven horses had double infestations with $D$. nitens.

Among the ticks identified, A. cajennense s.s. plays an important role in the ecoepidemiology of $R$. amblyommatis. MARTINS et al. (2016) only reported $A$. cajennense s.s. ticks, which belong to the A. cajennense complex in the "Baixada Maranhense" region (i.e. Equus caballus with $A$. cajennense s.s. in Santa Helena, Maranhão; E. caballus with A. cajennense s.s. in Pinheiro, Maranhão; and Sus scrofa 
with A. cajennense s.s. in Viana, Maranhão). According to NAVA et al. (2014), this tick species is closely related to $R$. amblyommatis in the Amazon biome.

It should be noted that the high antibody endpoint titers against $R$. bellii show that this species may have been present among the horses evaluated in this study. $R$. bellii is the Rickettsia species most commonly infecting ticks that are of great importance in the epidemiology of spotted fever, i.e. A. sculptum, A. ovale and A. aureolatum in South America (PACHECO et al., 2008; SABATINI et al., 2010; TOMASSONE et al., 2010; MIRANDA \& MATTAR, 2014; COSTA et al., 2015, COSTA et al., 2017).

All the ticks collected from the animals were tested individually by means of PCR to search for Rickettsia spp. All the samples from D. nitens and $R$. (B) microplus tested negative. The results presented here differ from those of BERMÚDEZ et al. (2011), who detected $R$. amblyommatis at relatively high infection rates in $D$. nitens ticks in Panama.

Out of 18 specimens of $A$. cajennense s.s., three $(16 \%)$ contained DNA of $R$. amblyommatis, as demonstrated by DNA sequencing of both the glt $A$ and the ompA products. A consensus sequence of $350 \mathrm{bp}$ was obtained for the glt $A$ gene, which was shown to be $100 \%$ identical to corresponding sequences of $R$. amblyommatis in GenBank (AY375163, CP012420, KX099898 and KX434741). A consensus sequence of 469 bp was obtained for the omp $A$ gene, which was shown to be $99-100 \%$ identical to corresponding sequences of $R$. amblyommatis in GenBank (JX867426, KM245156, CP012420 and KT722804).

The importance of horses as reservoirs for the causative agent of Brazilian spotted fever comes from their large capacity to harbor high infestations of ticks. For example, under natural conditions, a single horse can be parasitized by over 50 thousand larvae, more than 12 thousand nymphs or 2 thousand adults of $A$. cajennense (LABRUNA, 2000).

$R$. amblyommatis plays a role as an agent of human disease, as suggested by DASCH et al. (1993), who observed a group of 12 soldiers presenting medium levels of fever and reactive antibodies against rickettsiae. Presence of this bacterium has been correlated with outbreaks of fever in humans and; moreover, in Maranhão A. cajennense s.l. has been reported parasitizing humans (REIS et al., 2013). In the region studied here, horses are used as a means of transportation and as working animals, which increases the level of the human-animal relationship and the risk of disease transmission. Hence, the present study is of importance for elucidating these factors. This study reinforces the hypothesis that $R$. amblyommatis is closely related to A. cajennense s.s. in the Amazon biome.

\section{CONCLUSION}

The racial group of the Baixadeiro horse in the microregion of the Baixada Maranhense is exposed to R. bellii and R. amblyommatis or to a strain very closely related to these. The tick Amblyomma cajennense s.s. is exposed to $R$. amblyommatis.

\section{BIOETHICS AND BIOSSECURITY COMMITTEE APPROVAL}

The present study received prior approval from the Ethics and Animal Experimentation Committee of the State Universidade Estadual do Maranhão (UEMA) (protocol no. 011/2012).

\section{ACKNOWLEDGEMENTS}

We are grateful to Dr. Marcelo Bahia Labruna of the Universidade de São Paulo (USP), for laboratory support. This research was financially supported by the Fundação de Amparo à Pesquisa e ao Desenvolvimento Científico e Tecnológico do Estado de Maranhão (FAPEMA), through a fellowship for EFAF.

\section{CONFLICTS OF INTEREST}

The authors declare no conflict of interest. The founding sponsors had no role in the design of the study; in the collection, analyses, or interpretation of data; in the writing of the manuscript, and in the decision to publish the results.

\section{REFERENCES}

ALMEIDA, Z.S. et al. Sumário executive para plano de ação na área de proteção ambiental da Baixada Maranhense. São Luís; Editora, 2013. 1v

ALVES A.S. et al. Seroprevalence of rickettsia spp. in equids and molecular detection of "Candidatus Rickettsia amblyommii" in Amblyomma cajennense sensu lato ticks from the Pantanal region of Mato Grosso, Brazil. Journal of Medical Entomology, v. 51, n. 6, p. 1242-1247, 2014. Available from: <http://www.bioone.org/ doi/full/10.1603/ME14042 >. Accessed: May 26, 2017.

AMORIM, M.V. et al. Detection of antibodies of anti-Rickettsia spp. Indogs and horses in the state of Mato Grosso, Brazil. Semina: CiênciasAgrárias, v. 34, n. 6 Supl 2, p. 3755, 2013. Available from: $<$ http://www.uel.br/revistas/uel/index.php/semagrarias/article/ view/14182>. Accessed: May 26, 2017.

ANDERSSON, E. Seroprevalence of Rickettsia rickettsii and Rickettsia amblyommii in horses in three municipalities in the state of Pará, Brazil. [s.l: s.n.]. Examensarbete inom veterinärprogrammet, Uppsala 2013 Fakulteten för veterinärmedicin och husdjursvetenskap Institutionen för kliniska vetenskaper Kurskod: EX0736, Nivå A2E, 30hp. Available: $<$ http://stud.epsilon.slu.se/5630/>. Accessed: May 26, 2017.

BARROS-BATESTI, D.M. etal. Carrapatos de importânciamédicoveterinária da região neotropical: um guia ilustrado para identificação de espécies. São Paulo: Vox/ICTTD-3/Instituto Butantan, 2006. 223 p. BERMÚDEZ et al. Rickettsial infection in domestic mammals 
and their ectoparasites in El Valle de Antón, Coclé, Panamá. Veterinary Parasitology, v. 177, n. 1-2, p. 134-13, 2011. Available from: $<$ http://www.sciencedirect.com/science/article/pii/ S0304401710006576>. Accessed: Jan. 02, 2018.

COELHO, M.G. et al.Serologic evidence of the exposure of small mammals to spotted-fever Rickettsia and Rickettsia bellii in Minas Gerais, Brazil. Journal of Infection in Developing Countries, v. 10, n. 3, p. 275-282, 2016. Available from: $<$ https://jidc.org/index. php/journal/article/view/27031460>. Accessed: May 26, 2017.

COSTA, A.P. et al.A serological and molecular survey of Babesia vogeli, Ehrlichia canis and Rickettsia spp. among dogs in the state of Maranhão, northeastern Brazil. Brazilian Journal of Veterinary Parasitology, v. 24, n. 1, p. 28-35, 2015. Available from: <http:// www.scielo.br/pdf/rbpv/v24n1/1984-2961-rbpv-24-1-28.pdf>. Accessed: May 26, 2017.

COSTA, F.B. et al. Rickettsia amblyommatis infecting ticks and exposure of domestic dogs to Rickettsia spp. In an AmazonCerrado transition region of northeastern Brazil. PLoS ONE, v. 12, n. 6, p. 1-17., 2017. Available from: $<$ https://doi.org/10.1371/ journal.pone.0179163.pdf>. Accessed: Jun. 28, 2017.

DASCH, G. A. et al. Western blotting analysis of sera from military personnel exhibiting serological reactivity to spotted fever group rickettsiae. American Journal of Tropical Medicine and Hygiene (Suppl.), v. 49, n. 3, p. 220, 1993. Available from: <https://scholar. google.com/scholar>. Accessed: Jan. 02, 2018.

DUMLER, J.S. et al. Reorganization of gene in families Rickettsiaceae and Anaplasmataceae in the order Rickettsiales: unification of some species of Ehrlichia with Anaplasma, Cowdria with Ehriichia with neorickettsia, description of six new species combinations and designations. International Journal of systematic and evolutionary microbiology, v. 51, n. 2001, p. 2145-2165, 2001. Available from: <https://www.ncbi.nlm.nih.gov/ pubmed/11760958>. Accessed: May 26, 2017.

GUEDES, E. et al. Detection of Rickettsia rickettsii in the tick Amblyomma cajennense in a new Brazilian spotted fever-endemic area in the state of Minas Gerais. Memórias do Instituto Oswaldo Cruz, v. 100 , n. 8, p. 841-845, 2005. Available from: <http://www.scielo.br/ scielo.php?script $=$ sci arttext\&pid $=$ S0074-02762005000800004\&lng $=$ en\&nrm=iso\&tlng=en $>$. Accessed: May 26, 2017.

HORTA, M. C. et al. Experimental Infection of Opossums Didelphis aurita by Rickettsia rickettsii and Evaluation of the Transmission of the Infection to Ticks Amblyommacajennense. Vector-Borne and Zoonotic Diseases, v.9, n.1, p.109-118, 2009. Available from: $<$ https:// www.ncbi.nlm.nih.gov/pubmed/18945194>. Accessed: May 26, 2017.

IBGE. INSTITUTO BRASILEIRO DE GEOGRAFIA E ESTATÍSTICA - IBGE, Pecuária. 2011. Available from: <http:// www.ibge.gov.br/home/>. Accessed: May 26, 2017.

KARPATHY, et al. Rickettsia amblyommatis sp. nov.,a spotted fever group rickettsia associated with multiple species of Amblyomma ticks in North and South America. International Journal of Systematic and Evolutionary Microbiology, v. 66, p. 5236-5243, 2016. Available from: <http://ijs.microbiologyresearch.org/content/ journal/ijsem/10.1099/ijsem.0.001502>. Accessed: May 26, 2017.

LABRUNA, M.B. Aspectos da biologia e epidemiologia dos carrapatos de eqüinos no Estado de São Paulo. 2000. 76f. Tese (Doutorado em Epidemiologia Experimental e Aplicada a Zoonoses)
- Curso de Pós-graduação em Epidemiologia Experimental e Aplicada a Zoonoses, Universidade de São Paulo. Available from: $<$ http://www. scielo.br/scielo.php?script=sci_nlinks\&ref $=000062 \&$ pid=S0103>. Accessed: Jan. 03, 2018.

LABRUNA, M.B. et al. Prevalence of Rickettsia infection in dogs from the urban and rural areas of Monte Negro municipality, western Amazon, Brazil. Vector borne and zoonotic diseases, v.7, n.2, p.249-255, 2007. Available from: <https://www.ncbi.nlm.nih. gov/pubmed/17627445>. Accessed: May 26, 2017.

LABRUNA, M.B. et al. Rickettsia bellii and Rickettsia amblyommii in Amblyomma ticks from the State of Rondônia, Western Amazon, Brazil. Journal of Medical Entomology, v.41, n.6, p.1073-1081, 2004a. Available from: <https://www.ncbi.nlm.nih.gov/pubmed/15605647>. Accessed: May 26, 2017.

LABRUNA, et al. Molecular evidence for a spotted fever group Rickettsia species in the tick Amblyomma longirostre in Brazil. Journal of Medical Entomology, v. 41, n. 3, p. 533-537, 2004b. Available from: <http://www.bioone.org/doi/abs/10.1603/00222585-41.3.533? journalCode=ment $>$. Accessed: May 26, 2017.

LABRUNA, M.B. Ecology of rickettsia in South America. Annals of the New York Academy of Sciences, v. 1166, n. 1, p. 56-66, 2009. Available from: <https://nyaspubs.onlinelibrary.wiley.com/doi/epdf/ 10.1111/j.1749-6632.2009.04516.x>. Accessed: Aug. 07, 2018.

LEMOS, E.R.S, et al. Epidemiological aspects of the Brazilian spoted fever: serological survey of dogs and horses in an endemic area in the state of São Paulo, Brasil. Revistado Instituto de Medicina Tropical de São Paulo, v. 38, n. 6, p. 427-430, 1996. Available from: <http://www.scielo.br/scielo.php?script=sci_artte xt\&pid=S0036-46651996000600007>. Accessed: May 26, 2017.

MANGOLD, A.J. et al. Mitochondrial 16S rDNA sequences and phylogenetic relationships of species of Rhipicephalus and other tick genera among Metastriata (Acari: Ixodidae). Parasitology Research, v.84, n. 6, p. 478-484, 1998. Available from: <https:// link.springer.com/article/10.1007\%2Fs004360050433>. Accessed: Mar. 6, 2018.

MARTINS, M.E.P; MARTINS, K.C.S. Riquetsioses (Rickettsia spp.) transmitidas por carrapatos. Enciclopédia Biosfera, v. 10, n. 18, p. 273556, 2014. Available from: <http://www.conhecer.org.br/enciclop/2014a/ AGRARIAS/riquetsioses.pdf $>$. Accessed: May 26, 2017.

MARTINS, T.F. et al. Geographical distribution of Amblyomma cajennense (sensu lato) ticks (Parasitiformes: Ixodidae) in Brazil, with description of the nymph of $A$. cajennense (sensu stricto). Parasites \& Vectors, v. 9, n. 1, p. 186, 2016. Available from: $<$ http://www.pubmedcentral.nih.gov/articlerender.fcgi?artid=48 $18509 \&$ tool $=$ pmcentrez\&rendertype $=$ abstract $>$. Accessed: May 26, 2017.

MIRANDA, J. \& MATTAR, S. Molecular detection of Rickettsia bellii and Rickettsia sp. strain Colombianensi in ticks from Cordoba, Colombia. Ticks and Tick Borne Diseases, v.5, n. 2, p. 208-12, 2014. Available from: <https://www.ncbi.nlm.nih.gov/ pubmed/24378078>. Accessed: Mar. 6, 2018.

MONTENEGRO, D.C. et al. Spotted fever: epidemiology and vector-Rickettsia-host relationship in Rio de Janeiro state. Frontiers in Microbiology, v. 8, n. 3, p. 505, 2017. Available from: $<$ http://journal.frontiersin.org/article/10.3389/fmicb.2017.00505/ full $>$. Accessed: May 26, 2017. 
NAVA, S. et al. Reassessment of the taxonomic status of Amblyomma cajennense (Fabricius, 1787) with the description of three new species, Amblyomma tonelliae n. sp., Amblyomma interandinum n. sp. and Amblyomma patinoin. sp., and reinstatement of Amblyomma mixtum KOCH, L. Ticks and Tick-borne Diseases, v. 5, n. 3, p. 252-276, 2014. Available from: <http://dx.doi.org/10.1016/j. ttbdis.2013.11.004>. Accessed: May 26, 2017.

NUNES,E.C. etal.Rickettsia amblyommii infecting Amblyomma sculptum in endemic spotted fever area from southeastern Brazil. Memórias do Instituto Oswaldo Cruz, v. 8, p. 1058-1061. 2015. Available from: $<$ https://www.ncbi.nlm.nih.gov/pmc/articles/PMC4708027/>. Accessed: Aug. 30, 2017.

OGRZEWALSKA, M. et al. Epidemiology of Brazilian spotted fever in the Atlantic Forest, state of São Paulo, Brazil. Parasitology v. 139, n. 10, p. $1283-1300,2012$. Available from: <http:// www.journals.cambridge.org/abstract_S0031182012000546>. Accessed: May 26, 2017.

PACHECO R, et al. Isolation of Rickettsia bellii from Amblyomma ovale and Amblyomma incisum ticks from southern Brazil. v. 13, n. 2, p. 1273-1279, 2008. Available from: <http://www.producao. usp.br/handle/BDPI/15404>. Accessed: May 26, 2017.

PAROLA, P. et al. Tick-borne rickettsioses around the world: emerging diseases challenging old concepts. Clinical Microbiology Reviews. v. 18, n. 4, p. 719-756, 2005. Available from: <http://cmr.asm.org/content/18/4/719.long $>$. Accessed: May $26,2017$.

PINTER, A.; LABRUNA, M.B. Isolation of Rickettsia rickettsii and Rickettsia bellii in cell culture from the tick Amblyomma aureolatum in Brazil. Annals of the New York Academy of Sciences, v. 1078, p. 523-529, 2006. Available from: <http:// onlinelibrary.wiley.com/doi/10.1196/annals.1374.103/pdf $>$. Accessed: May 26, 2017.

RAMOS, D.G.S. et al. Rickettsial infection in ticks from wild birds from Cerrado and the Pantanal region of Mato Grosso, midwestern Brazil. Ticks Tick-Borne Diseases. v. 6, p. 836 842. 2015. Available from: <https:/www.ncbi.nlm.nih.gov/ pubmed/26232933>. Accessed: Aug. 30, 2017.

RAOULT, D.; ROUX, V. Rickettsioses as paradigms of new or emerging infectious diseases. Clinical microbiology reviews, v. 10, n. 4, p. $694-719,1997$. Available from: <http://cmr.asm.org/ content/10/4/694.long>. Accessed: May 26, 2017.

REIS, F. S. et al. Ixodidae tick infestation in humans in Maranhão state, Brazil. Enciclopédia Biosfera, v. 9, p. 3577-3582, 2013. Available from: $<$ http://www.conhecer.org.br/enciclop/2013a/agrar. htm>. Accessed: Jan. 26, 2018.

REGNERY, R. L. et al. Genotipic identification of rickettsiae and estimation of intraespecific sequences divergence for portion of two Rickettsial gene. Journal of Bacteriology, v. 173, n. 5, p. 1576-1589, 1991. Available from: <https:/www.ncbi.nlm.nih.gov/ pmc/articles/PMC207306/>. Accessed: May 26, 2017.

SABATINI, G.S. et al. Survey of ticks (Acari: Ixodidae) and their rickettsia in an Atlantic rain forest reserve in the State of Sao Paulo, Brazil. Journal of Medical Entomology, v. 47, n. 5, p. 913-916, 2010. Avaliable from: <http:/www.ncbi.nlm.nih.gov/ entrez/query.fcgi?cmd=Retrieve $\& \mathrm{db}=$ PubMed\&dopt=Citation\&li st_uids=20939390>. Accessed: May 26, 2017.
SANTOS, et al. Descrição do manejo geral de cavalos pantaneiros na região do Pantanal. Boletim de Pesquisa e Desenvolvimento/ Embrapa Pantanal, v. 63, p. 1-20, 2005. Avalia blefrom: <http:// www.cpap.embrapa.br/publicacoes/online/BP63.pdf>. Accessed: May 26, 2017.

SANGIONI, et al. Rickettsial infection in animals and Brazilian spotted fever endemicity. Emerging Infectious Diseases, v. 11, n. 2, p. 265-270, 2005. Available from: $<$ https://www.ncbi.nlm.nih.gov/pmc/ articles/PMC3320454/pdf/04-0656.pdf>. Accessed: May 27, 2017.

SILVA, et al. Genetic variability in local Brazilian horse lines using microsatellite markers. Genetics and Molecular Research, v. 11, n. 2, p. 881-890, 2012. Available from: <https://ainfo. cnptia.embrapa.br/digital/bitstream/item/64128/1/gmr1483.pdf>. Accessed: May. 25, 2017.

SILVA, et al. First report of a Rickettsia asembonensis related infecting fleas in Brazil. Acta Tropica, v. 172, p. 44-49, 2017. Available from: $<$ https://www.ncbi.nlm.nih.gov/pubmed/28427962>. Accessed: Jul. $26,2017$.

SOARES, H. S. et al. Ticks and rickettsial infection in the wildlife of two regions of the Brazilian Amazon. Experimental \& Applied Acarology, v. 65, p. 125-140, 2014. Available from: $<$ https://www. ncbi.nlm.nih.gov/pubmed/25273064>. Accessed: Mar. 6, 2018.

SOUZA, et al. Experimental infection of capybaras Hydrochoerus hydrochaeris by Rickettsia rickettsii and evaluation of the transmission of the infection to ticks Amblyomma cajennense. Veterinary Parasitology, v. 161, n. 1-2,p. 116-121, 2009. Available from: <http:// www.sciencedirect.com/science/article/pii/S0304401708007085>. Accessed: May 27, 2017.

SPOLIDORIO, et al. Novel spotted fever group rickettsiosis, Brazil.Emerging Infectious Diseases, v. 16, n. 3, p. 521-523, 2010. Available from: <https://www.ncbi.nlm.nih.gov/pmc/articles/ PMC3322033/pdf/09-1338_finalD.pdf>. Accessed: May 27, 2017.

SZABO, et al. Ecology, biology and distribution of spotted-fever tick vectors in Brazil. Frontiers in cellular and infection microbiology, v. 3, n. July, p. 27, 2013. Available from: <https://www.ncbi.nlm. nih.gov/pmc/articles/PMC3709097/pdf/fcimb-03-00027.pdf >. Accessed: May 27, 2017.

TOMASSONE, et al. Detection of "Candidatus Rickettsia sp. strain Argentina" and Rickettsia bellii in Amblyomma ticks (Acari: Ixodidae) from Northern Argentina. Experimental and Applied Acarology, v. 52, n. 1, p. 93-100, 2010. Available from: $<$ https://www.ncbi.nlm.nih.gov/pmc/ articles/PMC3072707/pdf/nihms-282317.pdf $>$. Accessed: May 27, 2017.

UENO, T.E.H. et al. Experimental infection of horses with Rickettsia rickettsii. Parasites \& Vectors, v. 9, n. 1, p. 499, 2016. Available from: <http://parasitesandvectors.biomedcentral.com/ articles/10.1186/s13071-016-1784-y>. Accessed: May 27, 2017.

VIANNA, et al. Rickettsial spotted fever in Capoeirão village, Itabira, Minas Gerais, Brazil.Revista do Instituto de Medicina Tropical de São Paulo, v. 50, n. 5, p. 297-301, 2008. Available from: $<$ http://www. scielo.br/pdf/rimtsp/v50n5/a09v50n5.pdf>. Accessed: May 27, 2017.

WITTER, R. et al. Rickettsial infection in ticks (Acari: Ixodidae) of wild animals in midwestern Brazil. Ticks and Tick-borne Diseases, v. 3, p. 415-423, 2016. Available from: $<$ https://www.ncbi.nlm.nih.gov/pubmed/26775021>. Acessed: Aug. 30, 2017. 